\title{
教育講演
}

\section{4. 高カルシウム血症の臨床}

\section{永田 直一}

Key words：Ca感知受容体，原発性副甲状腺機能立進症，恶性腫瘍に伴う高Ca血症，ビスホスホネート

はじめに

高カルシウム $(\mathrm{Ca})$ 血症に関わる話題から, なるべく臨床に結びついた比較的新しい話題を 紹介したい。

\section{1. 血清Ca濃度の調節とCa感知受容体}

血清Caは副甲状腺細胞がセンサーとして機 能して, 副甲状腺ホルモンPTHを産生・分泌 し，またPTHに対し活性ビタミンDの産生があ たかもACTHに対するコルチゾールのごとく反 応することによって調節されている。この PTH-ビタミンD系という腸管Ca吸収を高め,

腎よりのCa排泄を抑え，また骨からのCa動員 を促進する強力な機構が存在することによって 我々はCaの体外への培失, 骨への沈着による 低Ca血症から逃れている，昨年，PTH作用の 標的となる25(OH) D-1 $\alpha$-水酸化酵素がクロー ニングされ，Ca調節系に重要な新しい一ペー ジが加えられだ。

中心的な役割を果たすPTHの分泌，合成の 調節機構の解明は著明に進歩した。特記すべき はすでに1993年になるが血清Ca濃度の変動を 感知する受容体がBrownらによってクローニン

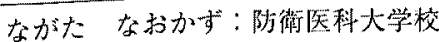

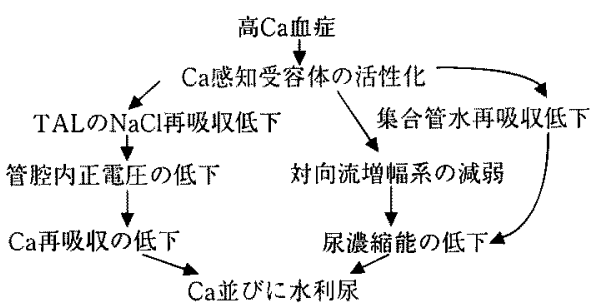

TAL: Thick ascending limb

図 1. Ca排泄と尿細管Ca感知受容体

グされたことである，血清Ca濃度の上昇はこ のG蛋白と共役した 7 回膜貫通型の受容体を活 性化し，その結果細胞内 $\mathrm{Ca}^{++}$濃度は上昇して PTH分泌を抑制するとともにPTH遺伝子の転 写を抑制する．PTH遺伝子の調節領域にはビ タミンDが抑制的に作用する部位とともに，Ca が抑制性に調節する部位が明らかにされてい る.このCa感知受容体は腎尿細管にも強く発 現し，留のCa排泄調節にも重要な役割を果た すとされる。細胞外液の $\mathrm{Ca}^{+}{ }^{+}$濃度の上昇はそ の活性化を来たし，Caの雨吸収を低下させる とともに水利尿を来すとされ，高Ca血症そし て高Ca尿症にともなう腎結石に対する防御機 構として働くという（図１）。こうしたCa感知 受容体についての研究の進展は, 臨床的な問題 の解明或いは進歩に具体的に結びついてい る2!。まず，この受容体の機能低下型の変異は 尿中Ca排泄を著明に低下させるとともに， Ca によるPTH分泌抑制の闇值を高めてPTHの不 
適切な過剩分泌をもたらし，家族性低Ca疗症 性高Ca血症（FHH）をまたそのホモの変異 では新生児重症副甲状腺機能立進症を起こす。

一方, 機能獲得型の変罢では逆の現象がみられ, 家族性低Ca血症或いは散発性副甲状腺機能低 下症を来すことが明らかにされてきたことであ る3．また後でも述べるようにこの受容体にCa 類似の活性化作用を持つ薬剂を開発し，機能䒕 進状態の治療に用いようとする試みがなされて いることも注目したい。

\section{2. 原発性副甲状腺機能方進症}

高Ca血症は血清Ca值の測定で発見される。 慢性疾患で長期に管理するような患者では少な くとも一度は測定しておくことが望まれる，特 に積極的に血清Caを测定すべき対象を表 1 に 挙げた。消化器，腎，精神神経系の症候，一般 検査での異常，或いは高Ca血症の頻度が高い といわれる基礎疾患や薬戍の服用中等である.

これらにはサルコイドーシスなどに由来する高 Ca血症もあるが，ここでは病囚として压倒的 に多い原発性副甲状腺機能立進症と悪性腫瘍に 伴った高Ca血症について述べる。

高Ca血症はPTH依存性と非依存性に大別さ れ，頻度はほぼ半分半分と見られる，前者が副 甲状腺の腺腫，過形成，癌による原発性副甲状 腺機能六進症であり，単発の腺腫が大部分を占 める，外来患者 1500 人から 2000 人に一人の頻度 と言われるが，米国では近年減少の傾向がある とされる゙

\section{1）副甲状腺病変と遺伝子異常}

副甲状腺腫湯の分子生物学的な解析がすすめ られ，種々な遺伝子異常が記載されている(表 2). 最も明確にされているのは第11染色体上 のPTH遺伝子とPRAD1/Cyclin D1遺伝子の再 構成であり，そのため細胞周期に関わり腫瘍原 性であるPRAD1/Cyclin D1の過剩発現が起こ るとされ，免疫組織学的検討では腺腫の約 $20 \%$
表 1，血清 $\mathrm{Ca}$ 值を测定したい症状や基筝疾患

\begin{tabular}{|c|c|}
\hline 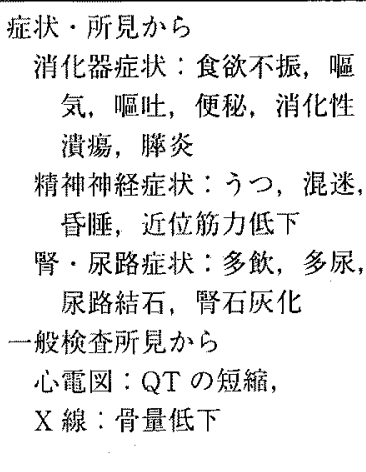 & $\begin{array}{l}\text { 基礎疾㭧から } \\
\text { 恶性腫痬 } \\
\text { サルコイドーシス } \\
\text { サ状腺譏能元進症 } \\
\text { 不動性 } \\
\text { アジソン病 }\end{array}$ \\
\hline
\end{tabular}

表 2. 原発性副甲状腺機能六進症の分子生物学

PRAD1/CyclinD1 造伝于とPTH 遗伀子の再㩐成

PRAD1/CyclinD1 遗伝子の過剩発現：腺腫

Loss of Heterozygosity (LOH) 1p, 6q, 9p, 11q, 15q

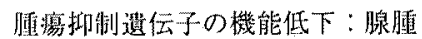

RET 遗伝子の活性型変珙

受容体型チロシンキナーゼの活性化：MEN2A

$\mathrm{MEN} 1 /$ menin 遗伝子の不活型変異

腫瘍抑制遗伝子の不活化：MEN1，腺腫

$\mathrm{Ca}$ 感知受容体の不活型変暴

ヘテロ：FHH ホモ：新生児重症副甲状腺機能元進症

$\mathrm{PTH} / \mathrm{PTHr}$ 受容体の活性型変異

Jansen 型覺端軟骨黑形成症

で証明されるというゔ.また副甲状腺腫には1 $\mathrm{p}, 6 \mathrm{q}, 9 \mathrm{p}, 11 \mathrm{q}, 15 \mathrm{q}$ \%loss of heterozygosity ( $\mathrm{LOH})$ が認められ，これらはなんらかの腫瘍 抑制遺伝子の機能低下を示すものとみられる。 頻度の高いのは1p及び11qの異常で, 散発性副 甲状腺腫ではそれぞれ40\%に認められている。 受容体型チロシンキナーゼをコードするRET 遺伝子の活性型変異がMEN2Aに，腫瘍抑制遺 伝子である $\mathrm{MEN1} / \mathrm{menin}$ 遺伝子の不活性型変 異がMEN1の腫瘍発生に関わることが明らかに され，MEN1遺伝子の変異は散発性腺腫にも認 められている ${ }^{6}$. Ca感知受容体の変巽による病 態は前述した。原発性副甲状腺機能元進症では Ca感知受容体の变異は認められていないが腺 腫や二次性副甲状腺機能立進症におうる組織で の免疫活性の低下が報告されている．またPTH 
の過剩分泌はないが, PTH/PTHrP受容体の機 能獲得型の変異のために高Ca血症を来すJansen型metaphysial chondrodysplasiaという特異 な病態の存在も明らかにされている7゙.

\section{2) 症候と診断}

症候については種々な統計があり，特異的な 症候を欠く化学型が約 $80 \%$ に及ぶという報告も あるが，尿路結石は診断の手がかりとして重要 である．1200例以上の手術例を纊めた甲状腺外 科検討会の成績でも発見の動機として腎病変が 34\%であるとしており，また最近，神戸大学の グループが䌆めたものでも尿路結石が最も多く 大部分の患者にはなにらかの症状があったとい $う^{81}$. 診断には高Ca血症とともにPTHの高值を 証明する．熏性腫湯やサルコイドーシスに伴う 高Ca血症等副甲状腺以外に原因のある高Ca血 症では高Ca血症に応じてPTHの分必は抑制さ れている.PTHの測定にはインタタトPTHが 高く評価される. 画像診断も沉用され, 多くの 場合にエコーゃCTで副甲状腺病変が証明され るが, 証明し難い場合には副甲状腺シンチを行

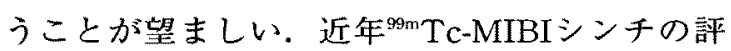
判が高いが果たしてこれが従来のTlを用いたシ ンチより勝るかどうかは更に経験の集積が必要 と思われる ${ }^{10 !}$.

\section{3）治療方針のたて方}

診断がつけば副甲状腺手術を勧めるのが一般 的であり，特に1991年合意の得られた適応基準 を满たす症例には手術が必要で，専門施設にお ける手術成績は極めて良い. (1) $12 \mathrm{mg} / \mathrm{d} 1$ 以上の 高Ca血症, (2) $400 \mathrm{mg}$ /日以上の高Ca尿症, (3)腎 結石, 線維性骨炎, 古典的神経 - 筋症状, (4)皮 質骨量の著明低下，(5)他の原因がなくて認めら れる腎機能の低下, (650歳以下，がこの手術適 応基準に挙げられている．その他に准骨等海 綿状骨に対する影響が高度にでる症例もあり，

手術の適応には椎体骨量や骨代謝マーカーも考 慮すべきと思われる. 近年骨代謝マーカーの 種々な代謝性骨疾患での検討が進んでおり，原
発性副甲状腺機能え進症では骨形成マーカー， 骨吸収マーカーともに増加が認められる。その うち骨吸収元進のマーカーであるコラーゲン架 橋のうち，デオキシピリジノリンは骨に特異性 が高いと評価されているが, 原発性副甲状腺機 能充進症に抢ける尿中排泄量は腰椎骨量と高い 逆相関を示すということで，本年 1 月に転移性 骨病変の診断とともに原発性副甲状腺機能立進 症の手術適応の判定を目的に保険適応となっ た：その有用性について今後の検討が望まれる. 最近原発性副甲状腺機能立進症患者では血中の IL-6, IL-6 soluble receptor，ならびにTNF- $\alpha$ の 濃度が高いことが報告された。抏そらく骨組織 での産生の元進が反映されているのであろう が、こうした高サイトカイン血症は骨に対する 影響だけでなく，しばしばみられる不定愁訴と 関わっている可能性がある゙'.

\section{4）保存的治療と薬物治療の可能性}

手術を行わない場合の管理では, 日常生活に 対する患者指導が大事である。嘔吐や下痢を伴 う疾患では脱水による高Ca血症の悪化を来す 可能性があり, 早期の受診を勧める。Caの摂 取についてはその制限は更にPTH分泌を高め る可能性があるので過少でも過多でもない600 〜 800mg/日程度が好ましいといえる。リンの 補充も同様にPTH分泌を促進し，また長期的 には軟部組織の石灰化を起こしうるということ で搉められない。一般に原発性副甲状腺機能立 進症では安定した血清Caレベルで無症状に経 過するが，手術などでストレスがかかったり， 不動性が加わったり，水バランスに問題が起こ ると急激に血清 $\mathrm{Ca}$ 值が上昇し, 消化器症状や 精神症状を起こすことがある。我々は最近，く も膜下出血で前交通動脈クリッピング後高 $\mathrm{Ca}$ 血症のため一時改善した意識が再び悪化した一 症例を経験したが，安定した時期には特別の処 置なく血清Ca值は $11 \mathrm{mg} / \mathrm{dl}$ 程度であった。

生活管理だけでなく，薬物による介入につい ては未だ定まったものはない. 閉経後の女性に 
多い疾患であることもありこうした症例にエ ストロジェン補充療法は骨の保護という観点か ら望ましい。たとえば 2 年間の観察で総ての部 位で, 骨量の改善がみられたという報告がある。 エストロジェン投与では骨代謝マーカーが低下 すると共に尿中Ca排泄は半減, 尿路結石の防 止にもよい結果を与えることが期待される。エ ストロジェン投与では血中PTHレベルは変化 せず，血清Ca值については変化しない，或い は $0.5 \mathrm{mg} / \mathrm{dl}$ 程度の低下があると報告されてい る ${ }^{12)}$. 骨吸収抑制薬であるビスホスホネートを 軽度の高Ca血症の持続的なコントロール並び に骨保護のために用いようとする試みがあり， 少なくとも一時的には有効であるとされる。し かし血清Ca值の低下に反応して血中PTH值は 有意に上昇し，そのためCa負荷後の血清Ca値 の上昇は顕著であるという ${ }^{13)}$ 。このようにPTH 分泌を更に刺激するような治療が果たして生体 に有用かどうか検討されなければならないだろ う.

一方PTHの分泌自体を薬物で抑える事が出 来ればこれは単なる対症的なものでなく特異的 治瘵といえる．最近前述のCa感知受容体に血 清Caの上昇と同椂なシグナルを送るcalcimimeticな非ペプチド性の化合物の臨床応用をめ ざしたトライアルが行われている. PhenylalkylamineであるNPS R568がアメリカで開発さ れ，本邦ではキリンにより KRN 568として原発 性並びに二次性副甲状腺機能立進症に対し第二 相の臨床試験が始められている，第一相におけ る連続投与では 1 日 2 回の連続投与によって， 朝投与 2 時間後のPTH值は明らかに低下がみ れるが，当日投与前には対照よりむしろ高値と なった。同じ試験で血清Ca值の動きをみると， PTHの様な值の動摇は無く連続投与中は当日 の投与前の值にも低下が認められている．最近 Silverbergらは軽症の原発性副甲状腺機能六進 症を持つ閉経後婦人20名にNPS R568を一回投 与した際の効果を報告し，その用量依存性の血

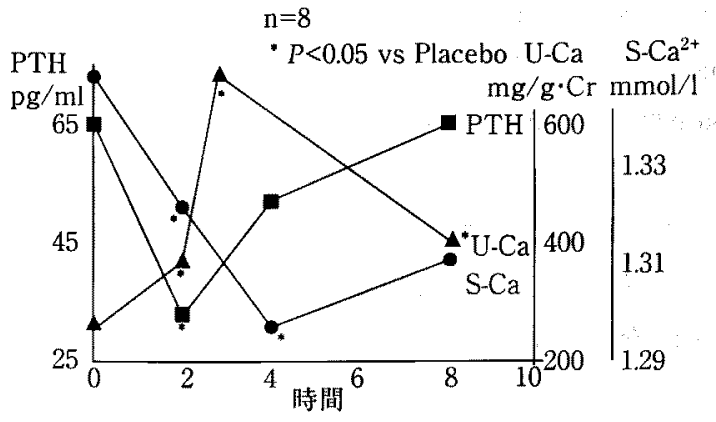

园 2．原発性副甲状腺機能九進症にR568（160mg）投 与の効果以

中PTHレベル低下効果を示した (図 2$)^{141}$. 興 味のある，また臨床応用への期待のもてる薬剤 である。

\section{3. 悪性腫瘍に伴った高Ca血症}

悪性腫瘍に伴う高Ca血症は高Ca血症全体の 䄪半数を占めるといわれるが，一般に高Ca血 症が高度になり，症状を呈し，また急速に臓器 障害を来しうるということで高Ca血症自体が 治療の対象となる重要な病態である。診療対象 によって大きく異なるが, 当教室では1980年代 の 3 年間に入院した約 200 例の悪性腫湯中 19 例 約 $10 \%$ に高Ca血症を認めた。大きく体液性因 子によるhumoral hypercalcemia of malignancy （HHM）と骨転移が顕著なlocal osteolytic hypercalcemia（LOH）に大別され前者が約 $80 \%$ を占めるといわれ，いずれにも副甲状腺ホルモ ン関連蛋白 (PTHrP) がホルモン或いは局所 因子として関与していることが多いといわれ る.

\section{1) $\mathrm{PTHrP}$}

PTHrPは1980年代に盛んに研究され高Ca血 症の起因因子としての意義は確立された。すで に血中濃度の測定は日常臨床に用いられ，PTH の測定と共に高カルシウム血症の診断に重要な 役割を果たしている. 我々の経験した悪性リン パ腫症例では病勢の悪化に伴い血中PTHrPの 
上昇, 血清 $\mathrm{Ca}$ 值の上昇がほほ並行して認めら れた ${ }^{(5)}$. PTHrPは種々の正常組織でも座生さ れ, 胎盤のCa輸送や平滑筋のトーヌス, 細胞 分化や增殖の調節因子としての機能について榆 討が進められている.PTHrPやその受容体欠 損マウスでは四肢などの形態異常を来すことか らその骨・軟骨形成に対する作用が示唆されて いたが, 最近Indian hedgehogがPTHrPを介し て軟骨細胞の分化を抑制する事が明らかにされ た ${ }^{16)}$.

\section{2）転移性骨病変による高Ca血症}

覀性腫瘍に伴う高Cal血症の約 $1 / 4$ は転移性骨 病変によるが，その診断には ${ }^{99 m} T c$ MDPを用い た骨シンチが最も敏感である，先述の骨代謝 マーカーを骨転移の診断に用いようする試みが あり ${ }^{17)}$, デオキシピリジノリンとtype I collagen carboxyterminal telopeptide (ICTP) は保 険適用となっている。癌研の小泉らは他の骨吸 収マーカーが閉経後の骨代謝回転の亢進によっ て変動するのにICTPは転移性骨病変でかなり 特異的に上昇することを示しておりこうした 病変による高Ca血症の診断の一助となろう。

3）治療薬，特にビスホスホネートについて 悪性腫瘍に伴う高Ca血症の治療は対症療法 となることが多いが，これには新世代のビスホ スホネートが登場して大きく変容した．血清Ca 值が $13 \mathrm{mg} / \mathrm{dl}$ 越すような高Ca血症では通常脱 水がみられ，腎からのCa排泄が制限されてい て，まず脱水を補正し，更に水・ $\mathrm{Na}$ 負荷を 行うが，しばしばその効果は不十分である。薬 物療法としては従来はカルシトニンが用いられ てきたが，現在では三種類のビスホスホネート が主役の座を奪った。これらは力価の違いはあ るが，臨床的な有用性には大きな差はないよう である、いずれも単回投与後, 大体投与 4 日で 明らかに効果がみられ，作用は一週間から10日 間持続，再投与も有効であるが，次第に効果が 減弱する症例もみられる。ビスホスホネートの 血清Ca低下効果は総て骨吸収の抑制に基ずく

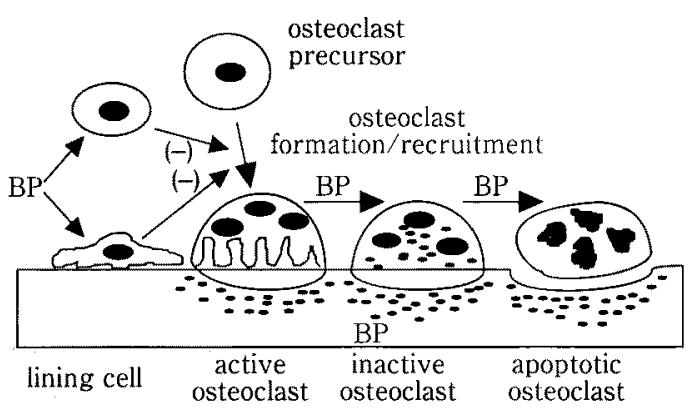

図 3.ビスホスホネートの骨吸収抑制機字㝵 $\mathrm{BP}$ :ビスホスホネート

ものであり, PTHやPTHrPによる腎からのCa 再吸收立進を抑えることは出来ず，こうしたホ ルモン作用が高度である場合には効果が弱い可 能性が指摘されている。 カルシトニンの特徵は 作用は弱く持続性に欠けるものの数時間という 早期に出現する. 従って高度の高Ca血症で症 状を呈する場合にはビスホスホネートを投与す るとともに，数日間カルシトニンを併用するこ とが薦められる ${ }^{18}$.

ビスホスホネートの作用機序には未知の点が あり，その作用点は破骨細胞の形成を抑える， 破骨細胞の活性を抑える，或いはそのアポトー シスを促進するなどの諸説があり（図 3$)^{199}$ ， 我々もマウスの骨芽細胞と骨髄細胞, 或いは脾 細胞との混合培盖において破骨細胞形成の抑制 を示した ${ }^{20)}$. 従って破骨細胞の活性化が関わる 転移性骨病変の成立や進展を抑制する効果がビ スホスホネートに期待され，メラノーマなどの 骨転移モデルではその効果がきれいに示されて いる.臨床的にも多発性骨䯣腫では 4 週に一回, $90 \mathrm{mg}$ のパミドロネートの点滴静注を行うと病 的骨折，骨病変のための放射線治療，乙して高 Ca血症を明らかに減少させることが報告され ている にパミドロネート $90 \mathrm{mg}$ 月一回投与を一年間投 与した結果ではプラセボ群に比べ病的骨折や放 射線治療や外科治療を要する合併症の発生頻度 が有意に低下することが示された22! 


\section{4）新規な骨吸収抑制分子}

最後に新しい話題として新規な骨吸収抑制物 質を紹介したい，最近破骨細胞の形成そしてお そらくはその活性を抑制するとみられるosteoprotegerinと呼ばれる分泌蛋白がクローニング された ${ }^{23)}$.この蛋白は別個に雪印乳業のグルー プにより単離され, osteoclastogenesis inhibitory factor (OCIF) と名付けられた ${ }^{24)}$. TNF 受容体スーパーファミリーに属する細胞外分泌 蛋白であり，骨芽細胞の産生する破骨細胞形成 に必須な因子と結合してその作用を阻害するも のとみられる．教室の赤津の検討ではマウスの 骨髄細胞培養系に種々な骨形成刺激因子を加え てみられる破骨細胞形成に対するOCIFの抑制 効果は極めて顕著で, 刺激因子が何であれ殆ど 完全な抑制がみられた。また以前に我々が高Ca 血症を来した膵癌患者から樹立したPTHrP産 生の細胞株FA-6を移植され，高Ca血症を来し たヌードマウスに腹腔内投与すると数時間で出 現する血清Ca低下効果をみることができた。 新しい骨代謝調節物質としてさらに検討される と思われる。

以上, 高Ca血症にまつわる比較的新しい話 題を紹介した. 副甲状腺腫痬学が遺伝子レベル で進展していること, Ca感知受容体が解明さ れたことにより幾つかの既知の病態の原因が明 らかにされたこと, 高Ca血症の治療薬として はビスホスホネート剤が普及して高く評価され ているが, さらにその骨転移そのものへの治療 応用, 副甲状腺機能立進症に対するPTH分泌 抑制薬の開発や新規な骨代謝制御物質の研究に も興味が持たれることを述べた.

\section{文献}

1) Takeyama $K$, et al :25-Hydroxyvitamin D3 l $\alpha$-hydroxylase and vitamin D synthesis. Science 277 : 1827, 1997.

2) Chattopadhyay $\mathrm{N}$, et al: The calcium-sensing receptor: A window into the physiology and pathophysiology of mineral ion metabolism. Endocr Rev $17: 289,1996$.

3) De Luca F, et al:Sporadic hypoparathyroidism caused by de novo gain-of-function mutation of the $\mathrm{Ca}^{2+}$-sensing receptor. J Clin Endocrinol Metab $82: 2710.1997$.

4) Silverberg S, Bilezikian JP : Primary hyperparathyroidism : Still evolving? J Bone Miner Res $12: 856,1997$.

5) Tahara H. Arnold A : Molecular basis of hyperparathyroidism. J Bone Miner Metab 15: 173, 1997.

6) Heppner $\mathrm{C}$, et al : Somatic mutation of the MEN 1 gene in parathyroid tumors. Nature Genetics $16: 375,1997$.

7) Schipani E, et al : Constitutively activated receptors for parathyroid hormone and parathyroid hormone-related peptide in Jansen's metaphyseal chondrodysplasia. New Engl J Med $335: 708,1996$

8) Kobayashi $T$, et al: Clinical and biochemical presentation of primary hyperparathyroidism in Kansai district of Japan. Endocr J 44 : 595, 1977.

9) Okazaki $R$, et al:Serum intact parathyroid hormone concentration measured by a two-site immunoradiometric assay in normal subjects and patients with various parathyroid disorders. Endocrinol Jap $39: 115,1992$.

10）小原孝男, 日下部きょ子：原発性副甲状腺機能立進症 のMIBIによる部位診断険查. Ann Rev内分泌，代謝 1997 (中外), p68, 1997.

11) Grey A, et al : Circulating levels of interleukin-6 and tumor necrosis factor- $\alpha$ are elevated in primary hyperparathyroidism and correlate with markers of bone resorption-A clinical research center study. J Clin Endocrinol Metab 81 : 3450, 1996.

12) Selby PL, et al: Ethinyl estradiol and norethindrone in the treatment of primary hyperparathyroidism in postmenopausal women. New Engl J Med 314 : 1481, 1986.

13) Reasner $\mathrm{CA}$, et al: Acute changes in calcium homeostasis during treatment of primary hyperparathyroidism with risedronate. J Clin Endocrinol Metab 77:1067, 1992.

14) Silverberg SJ, et al: Short-term inhibition of parathyroid hormone secretion by a calcium-receptor agonist in patients with primary hyperparathyroidism. New Engl J Med 337 : 1506, 1997.

15) Wada S, et al : Parathyroid hormone-related protein as a cause of hypercalcemia in a B-cell type malignant lymphoma. Intern Med 31 : 968, 1992.

16) Segre GV, et al: Parathyroid hormone-related protein and Indian hedgehog regulate the pace of cartilage differentiation. J Bone Miner Metab 15: 109, 1997.

17) Miura $\mathrm{H}$, et al: Diagnostic validity of bone metabolic markers for bone metastasis. Endocr J 44 : 751, 1997.

18) Wimalawansa SJ : Combined therapy with calcitonin and glucocorticoids, or bisphosphonate, for treatment of 
hypercalcemia of malignancy. J Bone Miner Metab 15: 160, 1997.

19) Rodan GA, Fleisch HA : Bisphosphonates: Mechanism of action. J Clin Invest $97: 2692,1996$.

20) Nishikawa $M$, et al : Bisphosphonates act on osteoblastic cells and inhibit osteoclast formation in mouse marrow cultures. Bone $18: 9.1996$.

21) Berenson JR, et al : Efficacy of pamidronate in reducing skeletal events in patients with advanced multiple myeloma. New Engl J Med 334 : 488, 1996.
22) Hortobagyi GN, et al : Efficacy of pamidronate in reducing skeletal complications in patients with breast cancer and lytic bone metastases. New Engl J Med 335: 1785,1996

23) Simonet WS, et al: Osteoprotegerin: A novel secreted protein involved in the regulation of bone density. Cell $89: 309,1997$.

24) Tsuda $\mathrm{E}$, et al: Isolation of a novel cytokine from human fibroblasts that specifically inhibits osteoclastogenesis. Biochem Biophys Res Commun 234 : 137, 1997. 